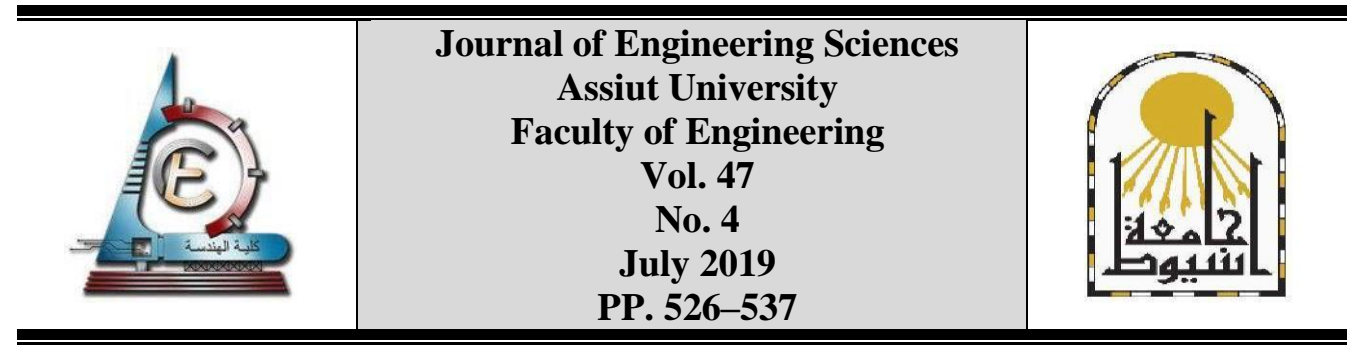

\title{
GREEN BUILDING INFORMATION MODELING (BIM) AND SUSTAINABLE DEVELOPMENT \\ CASE STUDY: UNIVERSITY OF CANADA, THE NEW ADMINISTRATIVE CAPITAL, CAIRO, EGYPT
}

\author{
Tamer Refaat $^{1,} *$, Ehab Hussien ${ }^{2}$ \\ ${ }^{1,2}$ Architecture Department, Canadian International College (CIC), Land \#6, Centeral \\ Services Area, South of Police Academy, Fifth Settlement, New Cairo.
}

Received 3 March 2019; Accepted 10 March 2019

\begin{abstract}
As a result of the political and economic developments taking place in Egypt to keep peace with other countries, the New Administrative Capital City is a beginning to achieve progress not only economically and socially but also environmentally. The project depends on meeting the user's social, cultural and economic needs without harming the surrounding natural environment and by using renewable energy to achieve the principles of sustainability and green architecture.

The aim of this research is to study the design and the effect of the New Administrative Capital City in economic and environmental, and how it achieves sustainability through urban design and detailed design. Also, discusses the different views of the project either positive or negative, with clear responses to negative views. Finally, it shows how could the New Administrative Capital City could be as a model to any designer want to create sustainable and ecofriendly city.
\end{abstract}

Keywords: Sustainable Development, New Administrative Capital City, Green BIM

\section{Introduction}

According to the concept of globalization, attention to technological development in all fields - especially architecture - has become very important in our time. So that, there has been a huge architectural boom resulting from the development of materials and methods of construction, which aimed to save time, effort and improve performance by taking into considerations the goals of sustainable development.

The development of ideas and visions resulted in the application of sustainable development principles so that, The United Nations (UN) asked various governments to integrate sustainable development goals into their national development plans and policies to ensure a better planet for future generations. This has resulted to a project that have been

* Corresponding author.

E- mail address: tamer_refaat@cic-cairo.com 
based on the principles of environmental conservation, pollution reduction, the usage of available resources and sustainable design in order to achieve sustainable city principles.

To insure that the urban and architectural design have been followed the goals of sustainability and achieve it with mathematical ratio, Building Information Modeling (BIM) and Green Building Modeling (Green BIM) models have emerged for the ease of dealing with the building in the stage of design, implementation, repair and maintenance to work with the existence of a timetable, which confirms ensuring the success of the project and the implementation of environmental and design goals.

The new administrative capital project, Cairo, Egypt is a major breakthrough in the field of urbanization and sustainable development, which aimed to create a first Sustainable City to be as a model in Egypt.

\subsection{Research problem}

The problem of research is as follows:

Lack of comprehensive planning and architectural applications which aimed to create an integrated sustainable environment and achieve design sustainability.

The concept of sustainable development focused on the environmental dimension, and neglected the use of natural resources and project's waste, so that we need to emphasize the integrity of the environment to ensure the integration of the three axes: Economical Approach, Environmental Approach and Social Approach.

Many designers do not care about using BIM software, although it is more accurate to link different design and implementation stages with measuring the environmental impacts of the project and its energy consumption.

\subsection{Research aims and goals}

The main objective of the research is to highlight a sustainable model in the field of urbanization and sustainability in Egypt - the new administrative capital project in Cairo, Egypt in order to gain the benefit from the positives and propose alternative solutions for the problems.

Use Design Builder as a type of Green BIM program to measure the effect of the chosen material in some buildings at the new administrative capital in energy consumption efficiency.

\subsection{Research structure}

The research explores the concept of sustainability and its objectives, then the definition of BIM programs. Also it presents the design and planning principles of the new administrative capital in Cairo, Egypt and how it achieved sustainability. Finally the suggestions to maximize efficiency and performance in order to complete the concept of sustainable city by using Design Builder Program to simulate the effect of some environmental materials in energy consumption efficiency.

\section{Sustainable development - general definition}

\subsection{Definition of sustainable development [1]}

The term "sustainable development" has emerged on the international and local scene to find its way among many contemporary terms. 
The 1987 report "Our Common Future" by the World Commission on Development and the Environment was the first one who refers to the concept of sustainability ${ }^{1}$. There are many special definitions on sustainable development. The most important:

- The development that meets the needs of people at the present time without compromising the ability of future generations to achieve their objectives.

- The 1987 Brundtland report of the International Commission on Environment and Development entitled "Our Common Future" defined sustainable development as "development that meets the needs of the present without compromising the ability of future generations to meet their needs."

Sustainable development is, in fact, a "comprehensive concept linked to the continuity of the economic, social, institutional and environmental aspects of society", to meet society needs with conservation of biodiversity, preservation of ecosystems to prejudice the rights of future generations to live a decent life.

\subsection{Sustainable Development Plan for 2030 [2]}

The Heads of State and Government were adopted on 25 September 2015 after the Special Summit on Sustainable Development "Sustainable Development Plan 2030". In January 2016, the implementation activities of these goals were officially launched. The plan is aimed at addressing the challenges of globalization based on the three components of sustainable development: the environment, society and the economy (Figure 1).

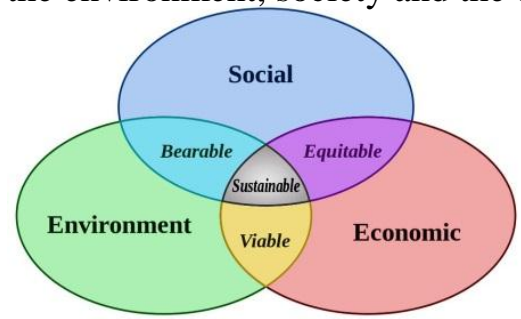

Fig. 1. Themes of sustainable development [3]

\subsubsection{Five pillars of sustainable development [3]}

The 2030 Sustainable Development Plan provides for the organization of activities and objectives around five pillars: Earth, Population, Prosperity, Peace and Partnerships. (Figure 2)

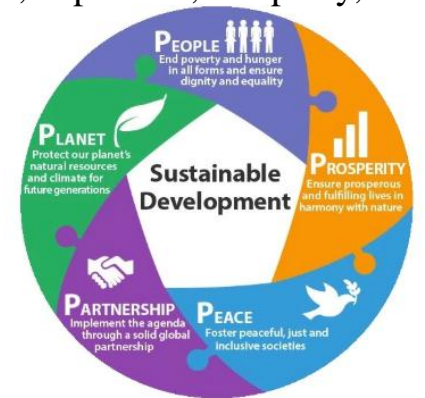

Fig. 2. Five pillars of sustainable development [4]

\footnotetext{
${ }^{1}$ This committee was formed by a decision of the General Assembly of the UN in December 1983 under the chairmanship of "Brundtland", Prime Minister of Norway and the membership of (22) members, in order to continue global economic growth without the needing radical changes In the global economic system.
} 


\section{First: Planet Earth:}

- To achieve water availability and sanitation services

- Access to sustainable energy

- Building sustainable cities

- Work for climate

- Conservation of the seas and oceans

- To safeguard biodiversity, land and forests

\section{Second: Population:}

- Eradicate poverty

- Eliminate hunger

- To ensure health and well-being

- Quality education

- Achieve gender equality

\section{Third: Prosperity:}

- Achieve sustainable economic growth and decent work

- Innovation and building resilient infrastructure

- Reduce inequality

- Sustainable consumption and production patterns

\section{Fourth: Peace:}

- To ensure the rule of law, justice and peace

\section{Fifth: Partnerships:}

- Renewal of partnerships and means of implementation

\section{Building information modeling (BIM)}

The BIM is defined as the design of a comprehensive model of the building with all its components and data. The 3D model goes beyond this, as it is intended to complete the construction, implementation and operation. This includes: construction as a 3D form, time factor (4D), cost factor (5D), sustainability factor (6D), and finally project management factor after operation and maintenance (7D). [5] (Figure 3) the term BIM was documented in 1992 by Van Nodervin and Tullman. [6]

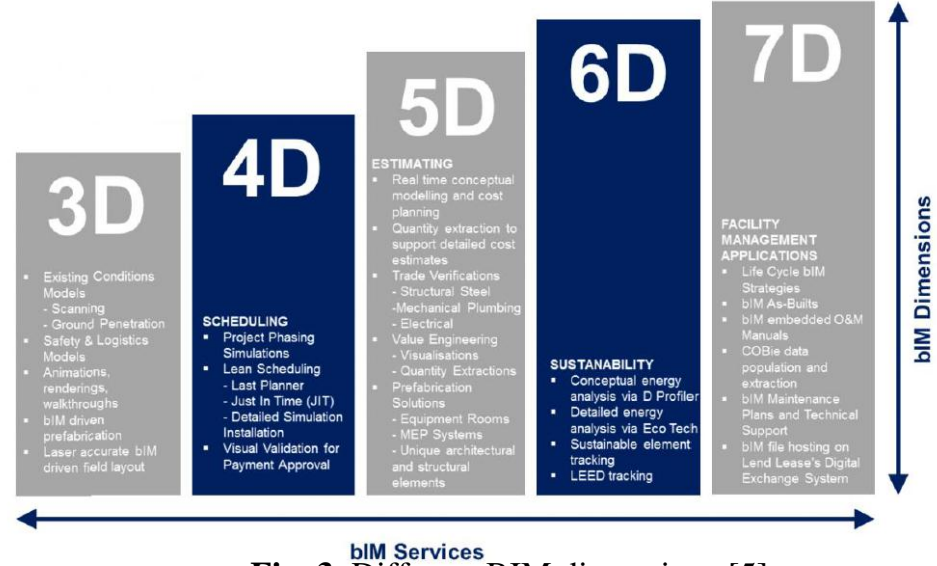

Fig. 3. Different BIM dimensions [5] 
By analyzing the Building Information Modeling (BIM) [5]

- Modeling: It is a visual model of data and information

- Information: Building data (construction materials, description, components, etc.)

- Modeling: All types of buildings (educational - industrial - residential - historical bridges - bridges ... etc.)

\subsection{Architectural BIM programs [5]}

- Autodesk Revit Architecture

- Nemetschek Allplan Architecture

- Gehry Technologies - Digital Project Designer

- Nemetschek Vectorworks Architect

- Rhino BIM (Beta)

\subsection{Sustainable BIM programs [5]}

- Design Builder

- Autodesk Green Building Studio

- Graphisoft EcoDesigner

\subsection{BIM Outputs [5]}

- Model of the public site

- Model of building block

- Architectural, structural, electromechanical and architectural drawings

- Project schedule and schedule

- Architectural, construction and electromechanical details

- Any other data agreed upon with the client or contractor

Through these outputs, the designer can obtain the following: [7]

1 - Simulation of the environmental effects of the building

2 - Energy consumption rates in the building

3 - Natural lighting rates inside the building

4. Final cost of the project

5. Project schedule

\section{Case study: university of Canada, the new administrative capital}

\subsection{Simulation program (design builder)}

DesignBuilder is software to assess the environmental performance efficiency of new and existing buildings, it also considers as easy-to-use simulation software that helps you to quickly assess the environmental performance of new and existing buildings. Models could be imported from BIM or built quickly by using the program's tools within. It provides fullyintegrated performance analysis including: energy and thermal comfort, design optimization, HVAC, daylighting (natural and artificial), cost, CFD, BREEAM and LEED credits, and reports that taking into its consideration the several national building certification standards. [8] 


\subsection{The new administrative capital}

The new administrative capital is aiming to create many opportunities for housing and work to address the various issues that facing Egypt and provide a smart life to adapt to the conditions of population growth and civilization. The new administrative capital is not only an economic project, but also it aims to achieve a range of economic, social and environmental development.

The planning has been characterized by a balance in the distribution of different uses such as: investment and commercial projects, administrative towers, industrial and residential areas, and an international airport, All of this is connected to a sophisticated highway network that accommodates traffic for more than 150 years. The design of the city is mediated by the Green River to be as a simulation of the Nile River which is in the middle of Cairo. (Figure 4)

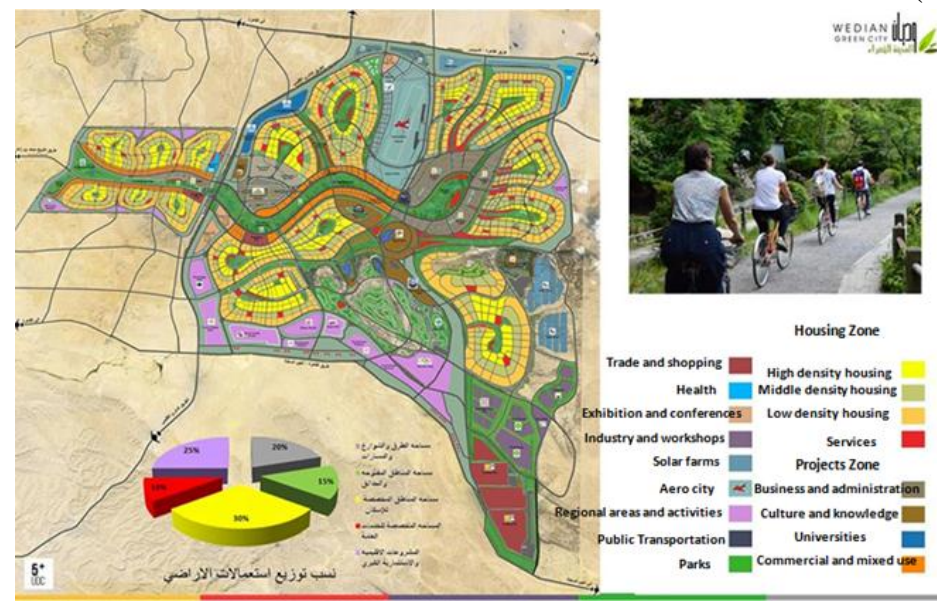

Fig. 4. Distribution of Uses in the Outline of the New Administrative Capital [9]

\subsection{University of Canada}

The planning idea of the new administrative capital included the presence of many international universities with accredited certificates to enhance cultural relations and facilitate the student's access to the scientific certificate without having to travel abroad. [10]

The design idea of the University of Canada (Figure 5) was based on not only being a vacuum containing many educational activities, but the idea was to be an environment friendly and sustainable place that leads to the educational purpose through:

- General orientation of the building

- Using an External coverage material to act as a buffer to reduce the thermal transferred inside the building, thus reducing energy consumption

- use PV cells on the top of the buildings

- water recycling 


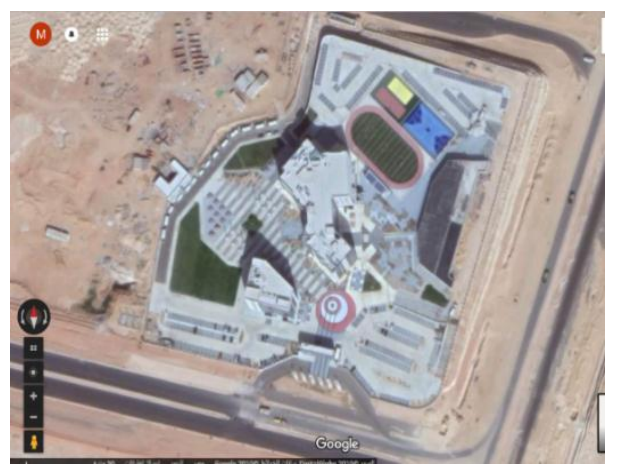

Fig. 5. University of Canada Layout [10]

The protection of the external envelope of the building was based on two means (Figure 6)

- Cover the external walls with marble

- Covering the inner walls of the courtyard with plants (Green Wall)

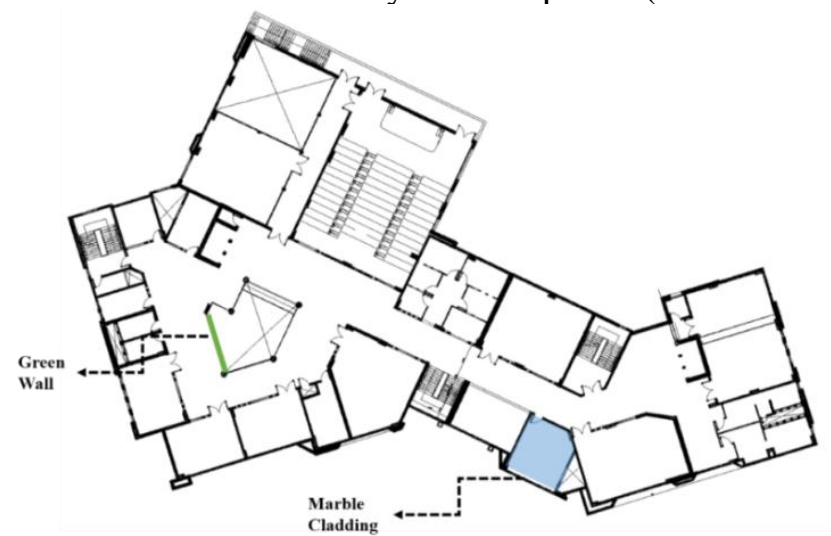

Fig. 6. Typical Plan for Engineering College

\subsubsection{Practical Study}

The practical study will be using design builder program to simulate the energy consumption in the initial case (environmentally friendly) and the case of regular building with no treatments in the building envelope

Practical case Studies:

1- Room 1: marble covering façade case

2- Wall 1: Planting covering façade case (Green wall)

\section{1- Room 1:}

- Room 1 is an academic staff room oriented in south west with Dimension 4.50*6.00 $\mathrm{m}$ with window to wall ratio (WWR) $15 \%$, Glass $6 \mathrm{~mm}$ - Single glazing.

- Room External wall Layers as shown in (Table 1) and the energy consumption of the room in initial and assumption case (Table 2) 


\section{Table 1.}

External Wall Layers

\begin{tabular}{|l|l|}
\hline & 0.02 m Marble \\
& 0.005 m Painting \\
& 0.025 m Cement Mortar \\
& 0.12 m Cement Blocks \\
& 0.025 m Cement Mortar \\
& 0.005 m Painting \\
\hline
\end{tabular}

Table 2.

Energy consumption of the room in initial and assumption case

\begin{tabular}{|l|l|l|l|l|}
\hline & $\begin{array}{l}\text { Cooling Load } \\
\text { K.Watt/hr }\end{array}$ & $\begin{array}{l}\text { Heating Load } \\
\text { K.Watt/hr }\end{array}$ & $\begin{array}{l}\text { Total energy } \\
\text { Consumption }\end{array}$ & $\begin{array}{l}\text { Saving in energy } \\
\text { Consumption Ratio } \\
\%\end{array}$ \\
\hline $\begin{array}{l}\text { Initial Case (with } \\
\text { marble) }\end{array}$ & 517.46 & 78.31 & 604.77 & $35.8 \%$ \\
\hline $\begin{array}{l}\text { Assumption Case } \\
\text { (without marble) }\end{array}$ & 813.95 & 128.43 & 942.38 & \\
\hline
\end{tabular}

(Figure 7) shows the difference in heating and cooling loads between the initial and assumption case

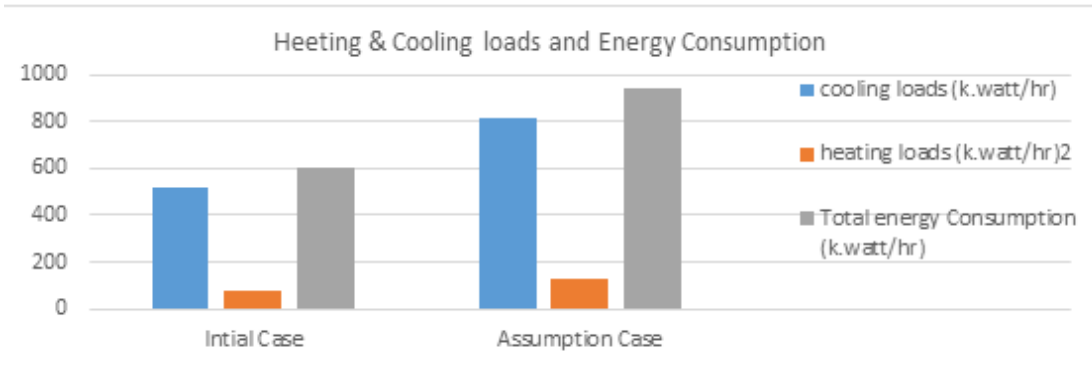

Fig. 7. Difference in heating and cooling loads between the initial and assumption case

\section{2- Wall 1:}

- Wall 1 is Courtyard wall oriented in south west.

- Room External wall Layers as shown in (Table 3), Plantation data as shown in (Table 4) and the thermal loads in initial and assumption case (Table 5)

Table 3.

External Wall Layers

\begin{tabular}{|l|l|}
\hline & $0.2 \mathrm{~m}$ Water Vapor \\
& $0.2 \mathrm{~m}$ Plantation thickness (Hedra Helix - IVY) \\
& $0.05 \mathrm{~m}$ Structure System (Stainless steel) \\
& $0.60 \mathrm{~m}$ Air Gap \\
& $0.005 \mathrm{~m}$ Painting \\
& $0.025 \mathrm{~m}$ Cement Mortar \\
$0.12 \mathrm{~m}$ Cement Blocks \\
& $0.025 \mathrm{~m}$ Cement Mortar \\
& $0.005 \mathrm{~m}$ Painting 0.05 \\
\hline
\end{tabular}




\section{Table 4.}

Plantation data

\begin{tabular}{|l|l|}
\hline \multirow{3}{*}{ Hedra Helix - IVY } & Specific Heat: $2800 \mathrm{~g} / \mathrm{kg}{ }^{\circ}$ Kelvin \\
& Thermal transfer: $0.36 \mathrm{~W} / \mathrm{m}$ Kelvin \\
& Density of leaves: $533.288 \mathrm{~g} / \mathrm{m} 3$ \\
& Leaf Area Index ( LAI): $0.005 \mathrm{~m} 2 /$ sheet \\
\hline \multirow{3}{*}{ Water Vapor } & Specific Heat: $1966 \mathrm{Gul} / \mathrm{kg}$ Kilvin \\
& Thermal transfer: $5.56 \mathrm{~W} / \mathrm{m}$ Kelvin \\
& Density: $600 \mathrm{~g} / \mathrm{m} 3$ \\
\hline \multirow{3}{*}{ Air Gap } & Specific Heat: $1004 \mathrm{~g} / \mathrm{kg}{ }^{\circ}$ Kelvin \\
& Thermal transfer: $5.56 \mathrm{~W} / \mathrm{m}$ Kelvin \\
& Density: $1300 \mathrm{~g} / \mathrm{m} 3$ \\
\hline
\end{tabular}

\section{Table 5.}

Thermal loads in initial and assumption case

\begin{tabular}{|l|l|l|}
\hline & Thermal Load K.Watt & $\begin{array}{l}\text { Reduction in Wall Thermal } \\
\text { loads \% }\end{array}$ \\
\cline { 1 - 2 } Initial Case (with marble) & 7094.67 & \multirow{2}{*}{$44.1 \%$} \\
\cline { 1 - 1 } $\begin{array}{l}\text { Assumption Case (without } \\
\text { marble) }\end{array}$ & 12690.51 & \\
\hline
\end{tabular}

(Figure 7) shows the difference in Thermal loads in initial and assumption case

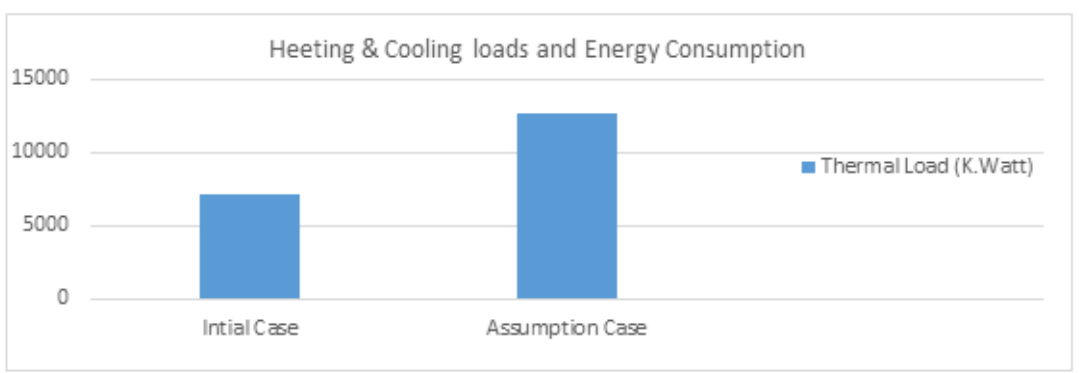

Fig. 8. Difference in Thermal loads in initial and assumption case

\section{Conclusion}

Due to the environmental problems that facing the world, designers should take into consideration the idea of sustainability and green architecture to minimize the negative effects of buildings on the environment

The design concept of the new administrative capital has been adopted as a guide for designer to know the way and the elements of designing a sustainable city, the capital's design concludes Buildings, Infra Structure, Landscape and transportation.

The practical study shows that building envelope protection (by using covering material or plantation) saves energy in Room 1 by $35.8 \%$ and minimize the thermal loads in wall 1 by $44.1 \%$, which reflected directly in thermal comfort and energy consumption efficiency and this reflected directly into reduction in $\mathrm{CO} 2$ emissions.

The isolation of the exterior of the building by plants reduces the effect of heat islands effect because it reduces the amount of re-emitted radiation and also creates an aesthetic image of the building. 
In the case of insulation of the buildings facades by using plants, the periodic maintenance of plants and its structural system must be maintained to ensure the efficiency of the system and also to maintain the integrity of the building from penetrating the roots, and finally .

\section{Recommendations}

Through previous studies, green buildings can significantly reduce the negative impact on the natural environment or eliminate it through high performance, market-leading design and environmentally friendly construction. Also it reduces the operational costs, enhance the marketability of building according to green design standards, and reduce the potential liability of the building resulting from indoor air quality problems.

In light of the high cost of construction that using traditional methods and the time required to complete all the works, from the foundations digging to the finishing stage we should have shed light on a new building system in the world such as Insulated Construction Forms (ICF).

\section{Insulated Construction Forms (ICF)}

The construction system of Insulated Construction Forms (ICF) is a double-edged concrete structure. These hollow structures are made of high density foam, which are stacked above some according to the shape of the desired building, then reinforced with internal reinforcement steel and finally filled with concrete (Figure 9).
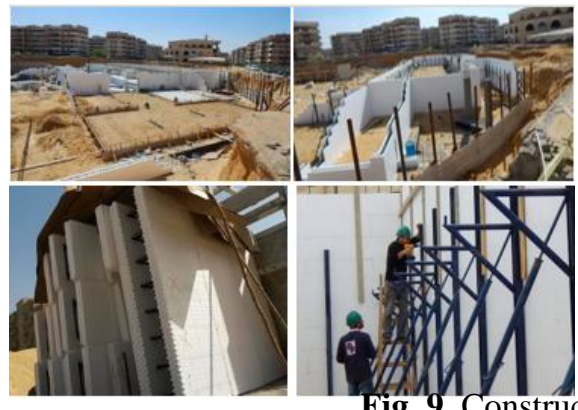

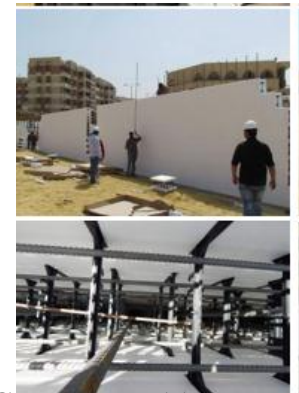

CF system [11]

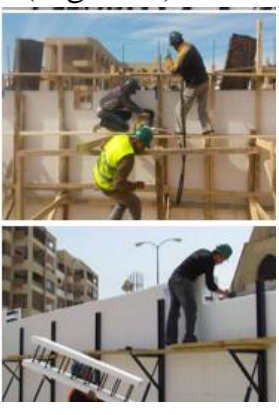

This system was implemented in Egypt in 2007 - on a small scale through the union with an American company also an international school has been established in the city of 6th October and 4 projects have been established for the armed forces.

Insulated Construction Forms (ICF) advantages: [10, 11, 12]

First: The implementing agency advantages:

- 5 times faster than conventional construction and it does not need the huge and deep foundations that we used in traditional constructions

- The dimensions of the structural unit are $120 \mathrm{~cm} * 40 \mathrm{~cm}$, which means that each unit covers an area equal to 6 times the unit of cement brick or 12 brick red brick, which saves about $80 \%$ of the time and cost.

- Reducing the percentage of damage

- Reduce the amount of concrete used to cast the ceiling.

Second: User advantages: 
- Does not require the skill of the workers for installation and the construction site will be clean without waste, and this system is cost-competitive.

- The system is soundproofed.

- Anti-fire system: The units resist the fire for up to 3 hours without reaching the fire to the concrete.

- Durability - Continuity: The structural units of this system have been a solution to seismic, cyclone and explosion-resistant areas. They are also resistant to shells. This is 5 times stronger than the traditional building, also because the concrete structures have a thick layer of insulation and high density which makes it the secret of continuity as the reinforcing iron (rebar) is not reached by moisture.

- The new system will increase its life time from 25 years to 75 years and it needs maintenance after 25 years of construction.

Third: The environment advantages - Environmentally friendly system -:

- Concrete and foam are antifungal, insect and waterproof.

- Can reduce the energy consumption required for construction by $44 \%$,

- The construction of this system does not result in negligible waste, and it guarantees 27 points of the LEED (international rating system).

- The foam used in the concrete structures is the same one which used inside the bodies of refrigerators and cups of hot drinks. Therefore, it saves heat or cold.

- The thermal insulation coefficient is $0.32-0.22$. This means a significant reduction in energy consumption by $60 \%$.

\section{REFRENCES}

[1] Fatima Mubarak, 2016, Sustainable Development: Origin and Arise. "Journal of the Environment of Electronic Cities", No. 13.

[2] Official website of French Diplomacy - https://www.diplomatie.gouv.fr - France Diplomatie - Ministe é re l'Europe de l'Europe et der Affaires e'strange res res

[3] https://www.hisour.com/themes-of-sustainable-development-39366/, Access on: February, 2019

[4] https://pressroom.oecs.org/implementation-of-sdgs-in-the-caribbean-region-the-importanceof-stakeholder-involvement, Access on: February, 2019

[5] Omar Selim, Mohamed Hammad.. etal, 2018, BIM Usage in Green Architecture

[6] E, Krygiel \& B. Nies. Green BIM: Successful Sustainable Design with Building Information Modeling. Retrieved from: http://bimarabia.com/os/?p=27073.

[7] Omar Selim, Sonia Ahmed, Moatasem Elbanna, Maison Elsrori, 2017, BIM Arabia, 8th Issue

[8] https://designbuilder.co.uk/about-us, Access on: February, 2019

[9] https://www.skyscrapercity.com/showthread.php?p=141752946, Access on: February, 2019

[10] Be Net for Construction Industry Factories, 2018, For Insulated Molds ICF Building System, http://www.cibenetc.com/en/project/- Molds- Insulated-icf- System-Construction /

[11] Your Architectural Magazine, 2018, ICF - Construction System with Die-cast Concrete, http://www.astucestopo.net/2015/01/icf.html

[12] al- emarat Ela'an, 23 June, 2018, Al Suwaidi builds eco-friendly homes without stonemason, https://www.emaratalyoum.com/local-section/other/2015-01-23-1.749306 


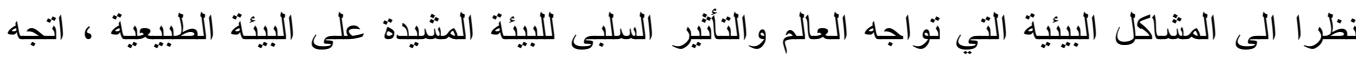

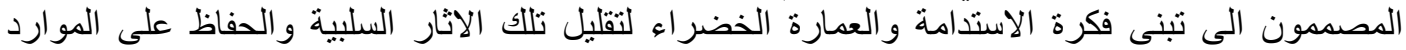
الطبيعية. لذلك تبنى مصمموا العاصمة الادارية الجديدة بالتجمع الخامس فكرة المدينة المستدامة من حيث الثيث التصميم و البنية التحنية ومصادر الطاقة والمو اصلات و عناصر تنسيق الموقع بحيث تصبح نموذجا لتصميم المدن فى المستقبل.

ولذلك ظهرت بر امج نمذجة المعلومات BIM لتدرس التأثير البيئى للمبانى قبل مرحلة التنفيذ وباستخدام برنامج Design Builder فى الدراسة العملية لدراسة تأثير معالجة الغلاف الخارجى لمبنى الجامعة الكندية بالقاهرة وتبين من تامحاكاه مايلى:

فى حالة تغطية الحائط الخارجى بالرخام لتقليل تأثثر الاحمال الحرارية على الحائط فى تم توفير الطاقة

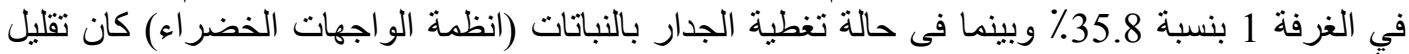

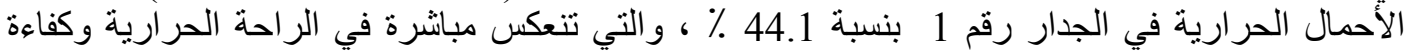

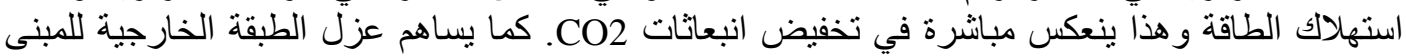
بالنباتات يقلل من تأثثر تأثثير حر ارة الجزر فئرة لأنها تقلل من كمية الإشعاع المنبعث.

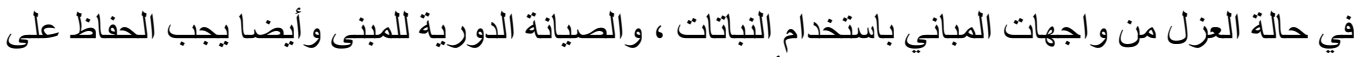

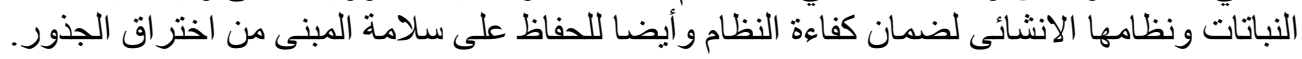

